\title{
WAS THERE AN ALTERNATIVE TO THE BALCEROWICZ PLAN? SHAPING THE ECONOMIC POLICY OF SOLIDARITY CAMP IN 1989
}

\begin{abstract}
The article describes the shaping of the Solidarity's economic policy in 1989 (from the elections in June until the implementation of the assumptions of the so-called Balcerowicz plan). The analysis includes both discussions between economists who support the Solidarity movement (such as Leszek Balcerowicz, Janusz Beksiak and Ryszard Bugaj) and the influence of international financial institutions and foreign creditors of Poland (such as the International Monetary Fund). The article presents the history of adopting neoliberal patterns of transformation, such as a centrally controlled economy and free market.
\end{abstract}

Keywords: polish transformation, Solidarity, Civic Parliamentary Club, the Balcerowicz Plan, Beksiak plan.

In May 1989, a few days before the parliamentary elections, Wojciech Jaruzelski sent a note to the top politicians of his team regarding the economic forecast for the country's development. This document, which contained extremely pessimistic prognosis on rapid deepening of crisis, was written in a style different from standard reports. One could say that it was almost hysterical - full of underlining, exclamation marks, and one of the main conclusions was written in capital letters: "WE ARE FACING THE BREAKDOWN 
OF THE FINANCIAL SYSTEM IN THE COUNTRY." ${ }^{1}$ That disaster, however, did not hit the communist government. In the autumn of 1989, Tadeusz Mazowiecki, one of Lech Wałęsa's closest advisors, took office of the Prime Minister. The country he inherited from his predecessors was on the verge of economic collapse.

The catastrophic state of the economy was no longer a secret by the summer of 1989. At the beginning of July, the government froze prices and wages, a month later marketization of food prices was introduced, which, in turn, resulted in a sharp rise of inflation. It turned out that the newly negotiated Round Table agreements became obsolete. In July, Ryszard Bugaj, one of the leading specialists in economy from the Solidarity camp, explained at one of the first meetings of the Civic Parliamentary Club (OKP), that the situation was so bad nobody had thought before: "we are on the verge of hyperinflation." 2 The condition of the state's finances was one of the elements discouraging the Solidarity opposition from sharing country's governance.

For a few weeks before taking the post of Prime Minister, Tadeusz Mazowiecki had published his famed text in "Tygodnik Solidarność" [Solidarity Weekly]. It was an answer to the political plans to take power from communists' hands. Mazowiecki asked rhetorically: "Do we have a program that can be presented to the public as a coherent concept of an exit from the economic crisis? Would it be accepted by society? Is it a program that can be implemented immediately?" 3 A month after the publication of the text, he accepted the proposed post of a Prime Minister. When asked by MPs and senators OKP about this sudden shift of opinion, Mazowiecki replied briefly: "It was not me who changed the mind, it is the situation that changed." It was merely an example of rhetoric acrobatics than a proper diagnosis of the situation. The lack of a program was the first obstacle to implementing effective reforms and addressing the challenges of governing the country. The second one was Solidarity's rather slim expert base.

Years later, Jerzy Regulski, the godfather of reconstruction of local government law - one of the most important reforms of the transformation period - explained where the weakness of the

\footnotetext{
${ }^{1}$ Alarm dla gospodarki [Alarm for the economy], May 22, 1989, note in the author's collection.

Archiwum Senatu, Protokół posiedzenia Prezydium OKP, 9 July, 1989, k. 42.

A. Brzeziecki, Tadeusz Mazowiecki. Biografia naszego premiera [Tadeusz Mazowiecki. The Biography of our Prime Minister], Kraków 2015, p. 405; T. Mazowiecki, Spiesz sie powoli [Make haste slowly], „Tygodnik Solidarność”, No. 7, July 14, 1989.
} 
solidarity camp had stemmed from. In his opinion, before 1989 the general opposition elite had concentrated on creating a civil society. Such thinking, however, had "a serious drawback in the long run: a complete lack of reflection on the country's reforms. It is not a coincidence that both Balcerowicz's reform and our local government reform came from the circles outside the opposition. Mainstream went in a different direction [than the Solidarity elite]. And when in 1989 it suddenly turned out that the democratic opposition was to participate in governing, the situation was dramatic. The drawers were empty." The two most important reforms - economic and of local government were planned and executed by two specialists loosely associated with Solidarity: Balcerowicz and Regulski.

Regulski's statement is illustrated by the chaotic search for the finance minister, the architect of economic reform, or, as Mazowiecki

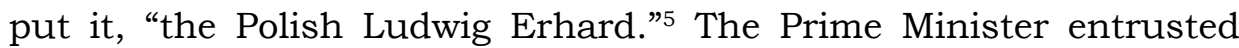
finding a new minister of finance to his friend and trusted colleague, Waldemar Kuczyński. It was a difficult task: "Prof. Witold Trzeciakowski, head of the Solidarity economic team at the Round Table, refused. He was reluctant to take a radical thrust, but he did not make any other suggestion. He indicated Cezary Józefiak (...) [He] also refused." ${ }^{6}$ Kuczyński recalled. Finally, he called Leszek Balcerowicz who did not even bother to return the call. Balcerowicz was convinced that Kuczynski was a journalist from Paris, asking only for a comment. A coincident decided that cooperation finally come through. ${ }^{7}$

Leszek Balcerowicz made history as the architect of the most important economic reform in Poland, replacing a socialist and centrally controlled economy with a capitalist one. This transformation claimed gigantic costs, especially for the society. Poland entered a period of transformation at the time of world triumph of neoliberal thought, implemented in line with the Washington consensus. Was there any chance of finding a different solution? Could Solidarity have created another plan? Could anyone else have been a historical reformer?

\footnotetext{
4 Tak, jestem pryncypialny, [Yes, I have principles], Dominika Wielowieyska talks to Jerzy Regulski, „Gazeta Wyborcza”, November 15, 2014.

5 A reference to the Minister of Economy in the government of Konrad Adenauer. Erhardt was recognized as the author of the post-war economic miracle in Germany.

6 Ten spisek sie spisat [This conspiracy worked out] - a dispute over 1989 and the Balcerowicz Plan. Agata Nowakowska and Dominika Wielowieyska talk with Waldemar Kuczyński, „Gazeta Wyborcza”, February 22, 2010.

A. Dudek, Od Mazowieckiego do Suchockiej. Polskie rzady w latach 1989-1993 [From Mazowiecki to Suchocka. Polish governance in 1989-1993], Kraków 2019.
} 


\section{OKP INITIATIVES - TRZECIAKOWSKI PLAN}

In the first weeks after the June elections, politicians from Solidarity were not proactive in creating their government. The leadership of the Civic Parliamentary Club (OKP) wanted to assume the role of a commentator and a controller of the activities of the communist Prime Minister. At the same time, however, there were plans to develop a proprietary basic framework for reforms. The Senate, in particular, was expected to become active because it consisted almost entirely of politicians from a Solidarity camp. ${ }^{8}$

Not only conceptual work was being done, there were also attempts to proactively implement some elements of their policy. As the Solidarity union had limited possibilities to influence the activities of the Rakowski government, they turned their interest abroad. The most well-known initiative was the so-called Trzeciakowski plan a call addressed to Western governments and institutions. Professor Witold Trzeciakowski was an economist associated with the Warsaw School of Planning and Statistics (then SGPiS) and the University of Łódź. He was a scholar with broad horizons, a scholarship holder at the Harvard and Columbia Universities. At the end of the 1980s, he became the key economic expert for Solidarity - he led the team for economy and social policy at the Round Table. As a senator he was in charge of the National Economy Commission.

His plan was in fact an appeal for financial support, complemented with a set of declarations. Their fulfillment by the Polish authorities was to guarantee (in theory) that foreign assistance would not be wasted. Tadeusz Kowalik quoted the main ideas of the plan in his book. The problem with their interpretation was that the individual points were of a general nature. Trzeciakowski referred, among other, to the content of the Round Table agreements, meanwhile the most important ones would be the details that characterized the process of rebuilding the economy. He pointed to elements such as: "a) elimination of administrative allocation and rationing of goods, services and financial resources b) formation of an anti-monopoly agency, c) expansion of the autonomy of state-owned enterprises, d) elimination of unprofitable enterprises, e) creation of a securities stock exchange at the beginning of 1991, f) the initiation in 1989 of a program setting out the speed and extent of the privatization of state

8 Archiwum Senatu, Protokół posiedzenia Prezydium OKP, 3 July 1989, ref. 2. 
property (including the means of production), in accordance with the Round Table Agreements, g) the achievement, over a period of time, at first internal and subsequently full convertibility of Polish zloty."

According to Trzeciakowski, rebuilding the economy based on these assumptions required a support of ten billion dollars over a period of three years. It was expected that the International Monetary Fund would include Poland into a three-year loan program of two billion 700 million dollars, the World Bank - a loan of another three billion. The creditors from the Paris Club were expected to formally approve of then current practice whereby Poland de facto did not pay interest and capital installments. Finally, under the bilateral agreements with Western countries, 4.3 billion in government guarantees for investment capital was expected.

This plan was meant to be the basis for talks between Solidarity envoys and Western leaders. Trzeciakowski presented the plan at the meeting with François Mitterand during his visit to Poland mid-June 1989. The French leader diplomatically described the concept as "interesting and courageous." He promised to present it at the next G-7 summit, which was to be hosted in Paris. ${ }^{10}$ At the beginning of July, the Solidarity delegation including Bronisław Geremek and Witold Trzeciakowski went to West Germany to present the plan at the meeting with Chancellor Helmut Kohl and Foreign Minister Hans-Dietrich Genscher, who also assured that Poland would not be left without support. ${ }^{11}$ The plan was also brought to London. Most importantly - it was most probably presented also to President George Bush during his visit to Poland. ${ }^{12}$ Although nobody refused the Solidarity delegates point-blank, it was clear that other than just words of support, there was nothing else to count on.

The concept of this diplomatic thrust must have been largely the realization of the idee fixe of Trzeciakowski himself. Stanisław Gomułka recalled his conversations with Trzeciakowski at the time: "He [was] fascinated by the possibility of obtaining foreign assistance. He even felt that such help was a sine qua non condition for the reforms' success. Meanwhile, it was completely unacceptable to me

9 T. Kowalik, From Solidarity to Sellout. The Restoration of Capitalism in Poland, Monthly Review Press, New York 2012, p. 73-75.

10 AŁ, Panowie, żadnych marzen, [Gentlemen, forget the dreams], „Gazeta Wyborcza”, July 5, 1989.

11 Archiwum Senatu, Protokół posiedzenia Prezydium OKP, July 9, 1989, pp. 30-32.

12 MT, Zachód o wizycie Busha [The West on Bush's visit], „Gazeta Wyborcza” July 10, 1989. 
(...) I considered the position of Trzeciakowski as naïve. He, however, was convinced of the necessity of large foreign aid and possibilities of obtaining it." ${ }^{13}$ Of course, Poland needed loans and foreign support to get out of the crisis. However, Gomułka's assessment was accurate and the plan to obtain a huge injection of money was unrealistic for several reasons. First, the IMF and the World Bank had a principle that financial transfers are released when the government of the country in question begins to implement reforms in line with their guidelines. Meanwhile, from their point of view, Warsaw had been using half-measures, partial or fake reforms for years, which pushed the economy towards hyperinflation and collapse. Moreover, there was no guarantee that any government - communist or of Solidarity camp - would be able to implement reforms facing social unrest. The International Monetary Fund assessed that together with the World Bank and private banks, they, at best, could send billion dollars annually to Poland in the foreseeable future.

While Western politicians had many kind words about Solidarity, they did not want to finance Polish reforms out of their pockets. Besides, for foreign governments and institutions, these proposals were very similar to what Wojciech Jaruzelski had already been presenting to them for a long time. It was him who sent a six-point plan requesting aid for Poland. Its objectives were close to those of Trzeciakowski, they contained promises of far-reaching economic changes, but then it was one-tenth of what Solidarity asked for at the time.${ }^{14}$ It should be emphasized that most countries were willing to talk about loans for Poland under the condition of concluding an agreement with the IMF. This mechanism was quite universal. The IMF experts, who came to a country that applied for loans, had wide access to all source materials describing the state of the country's economy. Not only were they in possession of confidential knowledge, but they also had extensive computer analysis programs to facilitate the processing of these data and to create economic models. For the international community, these were evidence of sorts (litmus test) - their decision to grant a loan resulted in granting another. Moreover, the IMF loan was usually subject to the creditor's consent to adopt draconian reforms, not only changing the structure of public

13 T. Kowalik (ed.), Stanisław Gomułka i transformacja polska. Dokumenty $i$ analizy 1968-1989 [Stanisław Gomułka and the Polish transformation. Documents and analysis 1968-1989], Warszawa 2010, p. 105.

14 W. Słowiński, Informacja [Information], „Gazeta Wyborcza”, July 14, 1989. 
spending but also opening the country's economy to import goods and services from abroad. It was one of the most effective instruments of globalization.

The French finance minister explained to his Polish counterpart that it was possible to give a guarantee for medium-term export loans, "but only after the agreement with the IMF has been agreed by Poland." 15 In May 1989, Peter Bryant, Undersecretary of State in the British Ministry of Trade and Industry, made it clear that "conditions to start financing of large projects have not been fulfilled yet, and a necessary condition (...) must be that Poland reaches the agreement in the Paris Club and agrees to an adjustment program with the IMF." 16 In July 1989, Margaret Thatcher wrote a letter to Jaruzelski. In it, she expressed her satisfaction that the Polish authorities noticed the need for agreement with the IMF and she ensured that she would stand with our country during the IMF's forum discussion. She solidarized in the face of the challenge: "The new economic plan for Poland for 1990-92 indicates the understanding that the IMF program will inevitably carry serious social consequences." ${ }^{17}$

The chances of obtaining foreign loans without the agreement with the IMF were minimal. It was one of the few reasons that Solidarity finally stopped pushing for the Trzeciakowski concept. He remained, however, on a very strong position of an economic advisor. The fact that he became the head of the Senate Committee on National Economy (KGN) demonstrated his position. After the election, the management of OKP had high hopes in the upper house of Parliament. As the Senate was nearly entirely controlled by opposition politicians, it could become an intellectual and law-making power base of Solidarity in the future. KGN was to be the place where the strategy of economic reforms was to be forged. This, however, did not happen. The Commission first met at the end of July but dealt only with current issues. It was only at the fifth sitting, on August 16 th, 1989, that the "program of bringing the economy out of crisis" was discussed. During the discussion, a demand to develop a reform

15 Archives of the Chancellery of the Prime Minister, Cabinet of Mieczysław Rakowski, $87 / 44$, Urgent note from financial talks conducted as part of the visit of French President F. Mitterand in Poland on June 14 to 16, 1989, c. 146.

16 AKPRM, Cabinet of Mieczysław Rakowski, 87/44, Urgent note from the secretary of state in MWGzZ Andrzej Wójcik on the 15th Session of the Polish-British Mixed Commission for Economic, Industrial and Scientific-Technical Cooperation, May 15, 1989, ref. 269.

17 AKPRM, Cabinet of Mieczysław Rakowski, 87/44, Letter from Thatcher to Jaruzelski, July 31,1989 , pp. 323 et seq. 
projects for sensitive areas of the economy was made. Committee members probably hoped that, in line with the expectations of the OKP leadership, they would build their own reform programs. However, when reading the chairman's remarks, one could get the impression that not only did he not encourage the commission to work but he wanted to discourage everyone from creating the program: "There was much disagreement between the coalition and the opposition party. What was agreed at the Round Table should be accomplished in the first place, and the balance of political powers in the Sejm should be taken into account." Ultimately, however, Trzeciakowski agreed to set up a team to devise the economic program under the pressure of other committee members. ${ }^{18}$ This decision was made a few days before Mazowiecki was appointed Prime Minister.

\section{OKP INITIATIVES - BEKSIAK PLAN}

When in August 1989 it turned out that the Senate committee might not meet due expectations, seeking other ways out started. On August 22, 1989 during the meeting of the OKP Presidium, Bronisław Geremek raised an issue of the economic program by pointing out the weakness of the newly appointed prime minister's cabinet: “[because] the government has no economic program, then we can suggest one and demand its implementation." 19 There were hopes to maximally expand the group of cooperating economists so as to include people with different views, who would cooperate with both government centers and the opposition. Members of the OKP Presidium began to nominate other names: Andrzej Celiński suggested that Stanisław Gomułka should get involved while Bronisław Geremek mentioned, among others, Janusz Beksiak, Grzegorz Kołodko and Leszek Balcerowicz. Eventually, as a very likely result of the arrangements between Bronisław Geremek and Jacek Kuroń, a team was formed and included, amongst others, Janusz Beksiak, Stefan Kurowski, Tomasz Gruszecki and Jan Winiecki. The team got three weeks to prepare a program's framework and another two weeks for the program's implementation. ${ }^{20}$ At the beginning of September, Bronisław Geremek issued an official statement that "the concept of a stabilizing program of the Polish economy and connected

\footnotetext{
18 Archiwum Senatu, Protokół posiedzenia Komisji Gospodarki Narodowej, August 16, 1989 , c.4 et seq.

19 Archiwum Senatu, Protokół posiedzenia Prezydium OKP, August 22, 1989, c. 2.

20 Archiwum Senatu, Protokół posiedzenia Prezydium OKP, August 30, 1989, c. 2.
} 
with it a systemic transformation towards a market economy" under Janusz Beksiak's direction was being devised. ${ }^{21}$

The group preparing this plan went down in history under the name "Beksiak's team." Beksiak was a long-time lecturer at the Warsaw School of Economics and a member of the PZPR (between 1977 and 1979 he was an academic advisor to the First Secretary of the Central Committee of the PZPR) he then joined Solidarity in 1980. At the end of the decade, Beksiak became a member of the Citizens' Committee (Komitet Obywatelski) and he participated in the round table talks with the leader of NSZZ "Solidarność, Lech Wałęsa. However, one person was important for this team - his political patron and the first formal leader: Jacek Kuron. He was the one behind this project. Kuron himself was quite vague about the genesis of this initiative: "I recognized (...) that people must get together to work, discuss, reject what is not suitable for Poland and work it out technicalities (...) it is the team that wants to work (...) they gathered around prof. Beksiak. I asked the Presidium [OKP] to work under their aegis." The work of the team, however, was not paid for by the OKP: "Sachs arranged money in the UN university for this team," Kuron explained. ${ }^{22}$ But money almost certainly did not come from any 'UN university'. Perhaps there were funds obtained from the National Endowment for Democracy or from a private pocket. George Soros financially supported Sachs' mission in Poland, perhaps he contributed to this project. ${ }^{23}$ In any case, when Bronisław Geremek informed the management of OKP about establishing this group, he clearly stated: "we set up a team of economic experts under the leadership of Jacek Kuron." ${ }^{24}$

It seemed that, at the beginning, the Kuron-Sachs duo drove that initiative. It was an unusual couple. Kuron was a dissident who began his political journey from orthodox communism to then turn towards revisionism and social democracy. On the other end there

${ }^{21}$ Beksiak's team started work on August 28, 1989. Initially, Janusz Beksiak, Tomasz Gruszecki, Jacek Kuroń, Aleksander Paszyński and Jan Winiecki worked in it. Then they were joined by: Jerzy Eysymontt, Aleksander Jędraszczyk, Stefan Kawalec and Dariusz Ledworowski, and Stefan Kurowski as a consultant. In the process, Eysymontt, Kuron and Paszyński resigned. Jerzy Dietl, Antoni Leopold, Jan Szomburg and Aleksander Szpilewicz as well as foreign consultants - Jeffrey Sachs, Dawid Lipton, Andrew Berg and Joshua Charap, contributed to the discussions. Marek Dabrowski, Piotr Perszewski and Witold Trzeciakowski participated in some meetings. Organization was handled by Grzegorz Lindenberg, Małgorzata Zajączkowska and Monika Kurpiel.

22 Archiwum Senatu, Protokół posiedzenia Prezydium OKP, September 5, 1989, c. 52.

${ }^{23}$ J. Sachs, The End of Poverty. Economic Possibilities for our Time, London 2005, p. 111.

${ }^{24}$ Archiwum Senatu, Protokół posiedzenia Prezydium OKP, August 30, 1989, c. 2. 
was Sachs - a liberal and supporter of shock therapy; Sachs had a reputation of the conqueror of Bolivian hyperinflation and debt loop. Kuron probably hoped for some time to become deputy Prime Minister responsible for economic and social affairs. What did Sachs count on? For sure, he wanted to be in the centre of events. His modus operandi was that, as an independent foreign advisor, he tried to maintain contacts with key politicians and Solidarity experts. In Brussels, he met with Trzeciakowski. In Poland, with the cream of the opposition, including Adam Michnik, Kuroń and Geremek.

Sachs later explained to Stanisław Gomułka that he gave Kuron a lot of attention as he suspected Kuron would become minister of finance. ${ }^{25}$ In his memoirs, Sachs wrote that his economic concepts influenced Kuroń so much that Kuron immediately demanded to write a plan to combat the crisis. ${ }^{26}$ This thread also appears in the journal Waldemar Kuczyński. He noted that it was actually Jeffrey Sachs who was behind Beksiak's team" (Beksiak himself said that "Sachs loyally cooperated"). Kuczyński was afraid that Kuron, as the deputy Prime Minister, would most likely implement Sachs recommendations. ${ }^{27}$

Kuron'Beksiak team worked from August 28 to September 28, 1989. The final report was presented to the leader of OKP, who sent it to the Prime Minister in early October 1989. The plan assumed a two-year long timescale of activities - it was to be finished by the end of December 1991. It consisted of three main parts: the outline of the stabilization program, the outline of the program for systemic changes and the timetable for implementing these changes. In general, the plan assumed in the first place to balance the budget and to reduce issuing money, through cuts in budget expenditures, withdrawal of tax breaks and imposition of new taxes and immediate suspension of lending projects. These were standard measures in hyperinflationary emergencies.

In the second part of the program, the need to "develop and shape Western-type market economy in Poland" was outlined, i.e. liberalization of economic relations and far-reaching limitation of state's influence on the economy. This was to be achieved by unblocking the regulations of prices, interest rates, pay rates, and

25 T. Kowalik (ed.), Stanisław Gomułka i transformacja polska. Dokumenty $i$ analizy 1968-1989 [Stanisław Gomułka and the Polish transformation. Documents and analysis 1968-1989], Warszawa 2010, p. 111.

${ }^{26}$ J. Sachs, The End of Poverty. Economic Possibilities for our Time, p. 113.

27 W. Kuczyński, Solidarność u władzy. Dziennik 1989-1993 [Solidarity in power. Journal 1989-1993], Gdańsk 2010, s. 11-12; Archiwum Senatu, Protokół z posiedzenia Prezydium OKP, October 5, 1989, c. 10. 
exchange rates. There were plans to review the regulations impeding economic activity, such as restrictions on land, housing, real estate, etc. Monopolies were to be liquidated. There were plans to create market economy institutions and also to change the role of the NBP (National Bank of Poland), create money market (stock exchange of short-term assets), capital market (stock and bond exchange) and, an antimonopoly office. Finally, the plan assumed privatization and its shape was to be a result of quickly reached political and social compromise. The team suggested that from January 1, 1990, 20 percent of shares of any state enterprise employing more than 250 people would be owned by employees, including the management of these enterprises - these shares would include the right to elect supervisory boards. The remaining 80 percent would stay in the state treasury. ${ }^{28}$ There were also considerations to make the remaining 80 percent available for sale in an unspecified future.

Beksiak's program was not implemented for several reasons. The political patron of the whole undertaking - Jacek Kuron - became a minister in Mazowiecki's government, but he took over labor and social affairs department, and not finance. He was not interested any more in findings of Beksiak's team. He was not the only one; the entire management of OKP began to distance themselves from this document. Bronisław Geremek diplomatically announced to Beksiak: "We will pass it on to the Prime Minister. We will not make it public as it is not our intention to control the government. Congratulations." Jan Rokita expressed himself more clearly: "It is [only] for the needs of OKP." Beksiak could not stand it: "It was not our intention to do this for political groups, for the Club. We did it for the country. We did not do this for the Club and please do not use it that way. This should be passed on to those who should deal with economic policy." Geremek ignored the outburst and closed the discussion: "We are facing political decisions. We will not give away the entire report." ${ }^{29}$ The leader of OKP did not want to fight for the lost cause.

However, it was not just about the difficult cooperation with the government. The key issue was that the chairman of OKP did not want to make the work of the team public. According to Tadeusz Kowalik, who at the time was talking to Geremek, he [Geremek] was

\footnotetext{
${ }^{28}$ J. Beksiak, T. Gruszecki, A. Jędraszczyk, J. Winiecki, Zarys programu stabilizacyjnego $i$ zmian systemowych [The outline of stabilisation program and systemic changes], Warszawa 1989, typescript, cc. 37-38.

${ }^{29}$ Archiwum Senatu, Protokół z plenarnego posiedzenia OKP, October 5, 1989 , cc. $7-11$.
} 
dissatisfied that a very liberal economic plan was created under the auspices of OKP. "He said that everyone went crazy, even Kuron completely adopted the market-privatization role of the government" Kowalik noted. Geremek was looking for another economist who would write a program with more focus on social issues. He talked about it with Tadeusz Kowalik and Ryszard Bugaj. ${ }^{30}$ During the meeting of the presidium of the OKP, Geremek informed in one breath that Beksiak's program would not be disseminated. At the same time, he mentioned about setting up a team to develop a "blended type program" that could be managed by Bugaj. ${ }^{31}$

It was undoubtedly an interesting initiative. Bugaj was one of the leading experts in Solidarity, and he distanced himself from neoliberal formulas for healing the economy. He was a regarded economist, chairman of the (Sejm's Economic Policy Commission, Plan, Budget and Finance). The problem was that Bugaj was marginalized by supporters of shock therapy. Already in July 1989, Jacek Kuroń preached: "this discussion has been going on for a long time: whether to do a market jump, that is a big jump onto the market, or what Rysiek Bugaj and Andrzej Wielowieyski have always preached, to do this in stages. I personally think that this is going to be a jump to the general market." ${ }^{\prime 2}$ Bugaj was gradually pushed into the back seat. The way he found out about the appointment of the Kuron/Beksiak team from the newspaper (from the interview given by Bronisław Geremek), says it all: "I tried to determine who is in the committee, asking some members of the Presidium [OKP] and I was unable to establish it," Bugaj recalled. Meanwhile, journalists and politicians rang him in this matter. And it turned out that one of the leading economists of OKP knew nothing about the action undertaken. He could not even initiate a solid discussion on the concepts of the economic recovery program. ${ }^{33}$ In response to one of Sachs' presentations, up against his growing popularity, Bugaj decided to present his ideas to fight the crisis. The media, according to the mode at the time, called this short draft plan "the Bugaj plan." The material reached both the Prime Minister Mazowiecki and international experts, but its political resonance was none.

${ }^{30}$ T. Kowalik, From Solidarity to Sellout. The Restoration of Capitalism in Poland, p. 117-118.

31 Archiwum Senatu, Protokół z plenarnego posiedzenia OKP, October 5, 1989, c. 10.

32 Archiwum Senatu, Protokół z plenarnego posiedzenia OKP, July 26, 1989, c. 78.

33 Archiwum Senatu, Protokół z plenarnego posiedzenia OKP, September 5, 1989, c. 29 . 


\section{SUPERMINISTER}

Balcerowicz was not the first choice of Prime Minister Mazowiecki for Minister of Finance. This position was proposed earlier to Prof. Trzeciakowski, who expressed his readiness to perform only advisory functions. Anyhow, looking at his other activities in the Senate Committee of National Economy, it was clear that he had abandoned the mission of creating a reform plan. The second choice was Cezary Józefiak, who also was not inclined to take on the burden of responsibility. Finally, Waldemar Kuczyński, who suggested these candidates to Mazowiecki, drew Balcerowicz's name. ${ }^{34}$ This is how a very original configuration was created, in which the Minister of Finance gained independence, which none of his predecessors and successors could even dream of.

First of all, it is necessary to take note of Mazowiecki's behavior as a Prime Minister. From the moment of being nominated, he became independent to a fault - both towards his political power base and also towards Lech Wałesa, the legend of Solidarity, and the actual leader of the opposition camp. Wałesa was not happy with the fact that Mazowiecki was trying to build its position at all costs, but the Prime Minister's and OKP's relations were even worse. The head of the Council of Ministers took the support of his power base for granted and he completely disregarded the signals from the deputies and senators. Bronisław Geremek explained that OKP had to pay "the price of all unpopular decisions that strongly dominated in the first months. Each of our deputy and senator met with voters who made us accountable for the activities of the government we appointed. At that time, it was hard to answer that although it was our government, we had no influence on its decisions." 35 It was not an isolated opinion, his view was also shared by the people critical of Geremek such as Jaroslaw Kaczynski who said: "OKP went through all sorts of changes, but at the same time [OKP] created very little dynamics of the situation (...) all this did not make OKP a place of political game. Everyone was speaking separately, and it did not resonate, there were no discussions. There was no politics. The government immediately

\footnotetext{
${ }^{34}$ W. Kuczyński, Solidarność u władzy. Dziennik 1989-1993. [Solidarity in power. Journal 1989-1993], Gdańsk 2010, pp. 11-13.

35 B. Geremek, Rok 1989 - Bronisław Geremek opowiada. Jacek Żakowski pyta [Bronisław Geremek talks, questions by Jacek Żakowski], Warszawa 1990, p. 312.
} 
became autonomous." ${ }^{36}$ Acting in such manner, Prime Minister had no intention of consulting the shape of economic reforms with OKP. Of course, for the sake of maintaining correct relations, government ministers were sent to the OKP meetings and explained the adopted direction of changes. However, they were deaf to the demands and doubts of parliamentarians.

As a result of such relations between the government and the political base, it was clear that the Finance Minister would not be obliged by any plans created under the OKP auspices. In addition, Balcerowicz, the architect of the new economy and then holding the position of deputy Prime Minister and Minister of Finance, was independent in his decisions. In honesty, a word independent was an understatement. Balcerowicz treated the Prime Minister in the same way as Mazowiecki treated OKP - he simply decided that his appointment meant a place for all necessary actions and decisions. He believed that regardless of everything the Prime Minister could not replace him in the middle of the operation, which would affect the reputation of the economy. As Aleksander Hall noted, Balcerowicz was endowed with a strong and even domineering personality. ${ }^{37}$ The result was then as was described by Waldemar Kuczyński: "Tadeusz [Mazowiecki] thinks that he is forced to buy a pig in a poke, Balcerowicz ignores him and runs his own policies behind his back (...). Allegations against Leszek are partly correct. Indeed, he neglects the Prime Minister (...) and [Mazowiecki] barely tolerates Leszek's independence, which at times borders on arbitrariness and being above the government." 38

If Mazowiecki felt ignored, it is difficult to describe how OKP parliamentarians must have felt. At the end of September 1989 one situation showed best how the new government sees the role of its political base. It was when Leszek Balcerowicz went to the Washington summit, where he presented the "Memorandum on the economic reform program in Poland and the role of foreign financial support." The problem was that no one from OKP had read it before. Deputies and senators were outraged by it.

${ }^{36}$ Alfabet braci Kaczyńskich [The alphabet of Kaczynski brothers], interview by M. Karnowski, P. Zaremba, Kraków 2010, p. 199.

37 A. Hall, Osobista historia III Rzeczypospolitej [Personal history of the 3rd Republic], Warszawa 2011, p. 78.

38 W. Kuczyński, Solidarność u władzy. Dziennik 1989-1993 [Solidarity in power. Journal 1989-1993], Gdańsk 2010, p. 29. 
Geremek himself observed: "it is an unacceptable situation when members of Polish parliament, members of OKP (...) find out from newspapers that there is a government economic program, that such a program was presented in the USA. We believe that a normal situation is that, before such program travels over the Atlantic, it is also presented in the country by the Vistula River." 39 Deputy Minister Marek Dabrowski came to the meeting of OKP, calmed down the gathering and explained the general directions of planned reforms. This was, however, only a courtesy move.

The climax in which OKP was finally dominated by the government in terms of economic legislation was December 1989, when they had to in fact agree to governmental projects without discussion, putting themselves in the position of a "voting machine". In order to speed up the work, an Extraordinary Committee was appointed to process the bills related to economic stabilization and systemic changes. The pace of the work was dizzying. Leszek Balcerowicz, when asked about the fact that the deputies had no idea what they voted for, answered years later: "I do not claim that they had full substantive knowledge but they knew that it was about something groundbreaking (...) Better people had a seat in the contract Sejm, there were fewer careerists (social climbers), and more competent people than afterwards." 40

The image presented by Balcerowicz was far from reality. Bronisław Geremek sometimes complained about the level of expertise of some deputies and senators and their narrow political horizons. This was not about the issue of worldview differences, but as a result of including of local activists on election lists, OKP was short of experts (eg. lawyers and economists). Andrzej Wielowieyski recalled how the attempts of creating "professional" lists of candidates were made before the election. ${ }^{41}$ What's more, the implementation of this legislative package was not based on the "good will of better people." OKP had no other choice after Lech Walesa mentioned, that it would be necessary to grant special authorities to the government to carry out the changes. At the meeting of the OKP Presidium a discussion took place on this subject. Some people were upset by condemning Wałęsa's "authoritarian" thinking. Nevertheless, one had to find a way out of the situation. Zbigniew Romaszewski wondered if endorsing and passing bills in the

${ }^{39}$ Archiwum Senatu [Senate Archives], a stenographic record of the meeting of OKP, 28 IX 1989, c. 3.

40 L. Balcerowicz, Trzeba sie bić [One has to fight], Warszawa 2014, pp. 131-132.

41 A. Wielowieyski, Losowi na przekór [Against the odds], Warszawa 2015, pp. 447-448. 
parliament without having a chance of reading or discussing it at that time was legally possible. Eventually Geremek closed the discussion stating, "we cannot argue with the government," and the laws must be passed quickly, one just needs to find a way to do so without breaking the law. During this period, Geremek and many politicians from the OKP leadership tried at all costs to prevent the internal disintegration of the Solidarity camp. Therefore, regardless of the club's assessment, full support was given to the Balcerowicz Plan.

\section{CONCLUSIONS}

Solidarity did not have a clear plan for economic reforms in 1989. They did not have to have one ready because, as a trade union and later as a parliamentary opposition party, Solidarity became a commentator and a critic of the communist authorities' activities. It was a completely rational strategy until the government with a Solidarity Prime Minister as a leader was formed. Mazowiecki was looking for his candidate for finance minister. A few serious economists rejected his proposal. The economic situation was so bad that it was clear that the new finance minister would be faced with drastic cuts in public spending and would be subjected to extraordinary political and social pressures and the fact that the Prime Minister did not consult his own political base did not help the situation. The leadership of the Citizens' Parliamentary Club (OKP) tried to create its own program, and then to present it to Mazowiecki. This so-called Beksiak plan was sometimes publicly described as an alternative to Leszek Balcerowicz's project. The problem is that both these plans really were of a similar shape. It is a phenomenon of sorts that the two groups selected by the fraction of the solidarity elite have developed neoliberal plans. Even more could be said - the consensus on this issue largely extended to all sides of the political dispute. The communists were building the foundations of a free market economy, especially during the rule of Mieczysław Rakowski and they too supported the "market jump."

Another element of this puzzle was the international situation at the time. The eighties and the nineties were the time of triumph of neoliberal ideology. The international community pushed through its foundations onto indebted countries of Latin America and Eastern Europe. The programs were implemented in accordance with the guidelines of the IMF, as an instrument of globalization. Its missions often came to Poland, especially since the mid-1980s, to monitor the 
directions of economic reforms. The IMF experts were quite critical of the actions of the Polish authorities - they believed that the reforms were too slow and superficial. The change at the helm of government was accepted with cautious optimism; the IMF saw the pro-market and pro-American attitude of the Mazowiecki cabinet and had high hopes for it. The Neoliberal direction of changes was also indicated by Western experts, especially Jeffrey Sachs, who became an adviser for both - Beksiak and Balcerowicz. The neoliberal direction of reforms was adopted with hardly any discussion, even though some economists raised their concerns. This was partly because the mechanisms of internal democracy and real discussion did not work in the Solidarity camp. The undivided power of the ruling elite was felt, especially while voting on the Balcerowicz plan in December 1989. The parliamentarians were brought to the role of a voting machine.

Many parliamentarians supported this project expecting that the Polish economy would quickly come close to the Western standards. However, they were given an imitation of the West, which they supported without knowing the economic realities. Misassumptions of the program had visible effects almost immediately. In 1991, the Economic Council at the Council of Ministers, led by prof. Witold Trzeciakowski, in their initial comments, warned about the shape of transformation: "the destruction of the old order must be, to a certain extent, balanced with making way for a new one." Joseph E. Stiglitz pointed out that Poland's transformation proved to be a success because, after the initial period, the government questioned the doctrine of the Washington consensus, at least with regard to privatization. ${ }^{42}$ At present, even the IMF and their economists distance themselves from the guidelines forced onto indebted states in the 1990s: "premature opening of the capital account... can hurt a country by making the structure of the inflows unfavourable and by making the country vulnerable to sudden stops or reversals of flows." ${ }^{43}$ The program implemented in Poland, in line with the IMF's universal adjustment programs, should not have been accepted in that shape in 1990. In the absence of market institutions, capital and effective state control mechanisms, rapid shock therapy was decided upon. It is difficult to say unambiguously whether history would have taken a different course if the reform program had been developed by

42 J.E. Stiglitz, Globalization and Its Discontents, New York 2002, p. 181.

43 Ha-Joon Chang, Bad Samaritans: The Guilty Secrets of Rich Nations and the Threat to Global Prosperity, London 2008, p. 88. 
an economist with more gradual approach to introducing changes. However, he would have had a chance to shape relations with international financial institutions in a different way and to propose a more prosocial plan.

\section{BIBLIOGRAPHY}

AKPRM, Cabinet of Mieczysław Rakowski, 87/44, Letter from Thatcher to Jaruzelski, July 31, 1989, pp. 323 et seq.

AKPRM, Cabinet of Mieczysław Rakowski, 87/44, Urgent note from the secretary of state in MWGzZ Andrzej Wójcik on the 15th Session of the Polish-British Mixed Commission for Economic, Industrial and Scientific-Technical Cooperation, May 15, 1989, ref. 269.

At, Panowie, żadnych marzen, [Gentlemen, forget the dreams], „Gazeta Wyborcza", July 5, 1989.

Alarm dla gospodarki [Alarm for the economy], May 22, 1989, note in the author's collection.

Alfabet braci Kaczyniskich [The alphabet of Kaczynski brothers] interview by M. Karnowski, P. Zaremba, Wydawnictwo M, Kraków 2010.

Archives of the Chancellery of the Prime Minister, Cabinet of Mieczysław Rakowski, 87/44, Urgent note from financial talks conducted as part of the visit of French President F. Mitterand in Poland on June 14 to 16,1989 , c. 146.

Archiwum Senatu [Senate Archives], a stenographic record of the meeting of OKP, 28 IX 1989, c. 3.

Archiwum Senatu, Protokół posiedzenia Komisji Gospodarki Narodowej, August 16, 1989, c.4 et seq.

Archiwum Senatu, Protokół z plenarnego posiedzenia OKP, July 26, 1989 , c. 78.

Archiwum Senatu, Protokół z plenarnego posiedzenia OKP, October 5, 1989. Archiwum Senatu, Protokół z plenarnego posiedzenia OKP, September 5, 1989 , c. 29.

Archiwum Senatu, Protokół posiedzenia Prezydium OKP, August 22, 1989 , c. 2.

Archiwum Senatu, Protokół posiedzenia Prezydium OKP, August 30, 1989 , c. 2.

Archiwum Senatu, Protokół posiedzenia Prezydium OKP, July 3, 1989, ref. 2 .

Archiwum Senatu, Protokół posiedzenia Prezydium OKP, July 9, 1989.

Archiwum Senatu, Protokół posiedzenia Prezydium OKP, September 5, 1989 , c. 52.

Archiwum Senatu, Protokół z posiedzenia Prezydium OKP, October 5, 1989, c. 10. 
Balcerowicz L., Trzeba się bić [One has to fight], Czerwone i Czarne, Warszawa 2014.

Beksiak J., Gruszecki T., Jędraszczyk A., Winiecki J., Zarys programu stabilizacyjnego $i$ zmian systemowych [The outline of stabilisation program and systemic changes], Warszawa 1989, typescript, cc. 37-38.

Brzeziecki A., Tadeusz Mazowiecki. Biografia naszego premiera [Tadeusz Mazowiecki. The Biography of our Prime Minister], Znak, Kraków 2015.

Dudek A., Od Mazowieckiego do Suchockiej. Polskie rzady w latach 1989-1993 [From Mazowiecki to Suchocka. Polish governance in 1989-1993], Znak Horyzont, Kraków 2019.

Geremek B., Rok 1989 - Bronisław Geremek opowiada. Jacek Żakowski pyta [Bronisław Geremek talks, questions by Jacek Żakowski], Plejada, Warszawa 1990.

Ha-Joon Chang, Bad Samaritans: The Guilty Secrets of Rich Nations and the Threat to Global Prosperity, Random House Business, London 2008.

Hall A., Osobista historia III Rzeczypospolitej [Personal history of the 3rd Republic], Rosner \& Wspólnicy, Warszawa 2011.

Kowalik T. (ed.), Stanisław Gomulka i transformacja polska. Dokumenty $i$ analizy 1968-1989 [Stanisław Gomulka and the Polish transformation. Documents and analysis 1968-1989], Wydawnictwo Naukowe Scholar, Warszawa 2010.

Kowalik T., From Solidarity to Sellout. The Restoration of Capitalism in Poland, Monthly Review Press, New York 2012.

Kuczyński W., Solidarność u władzy. Dziennik 1989-1993 [Solidarity in power. Journal 1989-1993], Europejskie Centrum Solidarności, Gdańsk 2010.

Mazowiecki T., Spiesz sie powoli [Make haste slowly], „Tygodnik Solidarność", No. 7, July 14, 1989.

MT, Zachód o wizycie Busha [The West on Bush's visit], „Gazeta Wyborcza” July 10, 1989.

Sachs J., The End of Poverty. Economic Possibilities for our Time, Penguin Books, London 2005.

Słowiński W., Informacja [Information], „Gazeta Wyborcza” July 14, 1989. Stiglitz J.E., Globalization and Its Discontents, W.W. Norton \& Company, New York 2002.

Tak, jestem pryncypialny, [Yes, I have principles], Dominika Wielowieyska talks to Jerzy Regulski, „Gazeta Wyborcza”, November 15, 2014.

Ten spisek sie spisat [This conspiracy worked out] - a dispute over 1989 and the Balcerowicz Plan. Agata Nowakowska and Dominika Wielowieyska talk with Waldemar Kuczyński, „Gazeta Wyborcza”, February 22, 2010.

Wielowieyski A., Losowi na przekór [Against the odds], Agora, Warszawa 2015. 